\title{
The Frequency of Blood Donors and Polycythemia among General Population in Nineveh Governorate, Iraq.
}

\author{
Rana Nidam Al-Deen Al-Nuri \\ Blood Transfusion Services Department, Nineveh Health Directorate , Mosul , Iraq \\ Correspondence: rnamalak@yahoo.co.uk
}

(Ann Coll Med Mosul 2020; 42 (2):141-147).

Received: $21^{\text {th }}$ Sept. 2020; Accepted: $22^{\text {th }}$ Nove. 2020.

\begin{abstract}
Objectives: the aim of the study is to determine the percentages of blood donors among general population in Mosul, Nineveh, Iraq, in an attempt to increase their proportion through encouraging healthy voluntary donation. Then to report the issue of polycythemia and discouraging the contributing unhealthy habits like smoking, especially among young people.

Methods: subjects enrolled in this study were the blood donors at Mosul Central Blood Bank in Nineveh, Iraq. Data were reviewed retrospectively, from March, 2019 to March 2020. For whole blood donors in general and for polycythemic ones, who donate blood as a therapeutic measure.

Results: the total number of donors were 36940 . Percentage of blood donors among general population was $2.27 \%$, while $99.43 \%$ were male donors. Prevalence of polycythemic subjects among general population of Mosul city was $0.04 \%$, among blood donors was $1.65 \%$. while $88.87 \%$ of polycythemic donors were male, and the distribution of polycythemia was higher in those aged 35 years and less (38.46\%).

Conclusions: the percentages of blood donors in general population was low, which need to increase through encouragement and improve commitment. The prevalence of polycythemic subjects in those aged $\leq$ 35 years was high which necessitate intensification of the awareness among those productive age groups.
\end{abstract}

Keywords: donation, hemoglobin , packed cell volume , polycythemia , smoking.

$$
\begin{aligned}
& \text { نسبة متبرعى الام وفرط كريات الدم الحمر بين سكان نينوى / العراق }
\end{aligned}
$$

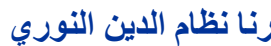

$$
\begin{aligned}
& \text { شعبة خدمات نقل الدم ، دائرة صحة نينوى ، نينوى ، العرين القوي }
\end{aligned}
$$

الاهداف: تهدف الدر اسة الى تحديد نسب المتبر عين بالدم بين عامة السكان فى الموصل ونينوى بالعر اق فى محاولة لزئ لزيادة نسبتهح من خلال تتجيع التبرع الطو عى الصحى. ثم الإبلاغ عن قضية فرط كريات الدم الحمر وتثنيط العادات غير الصحية الصنية الصساهمة مثل

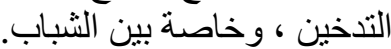

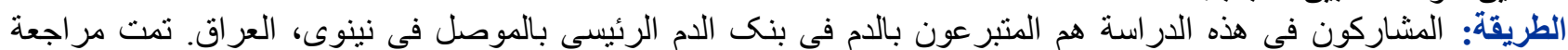

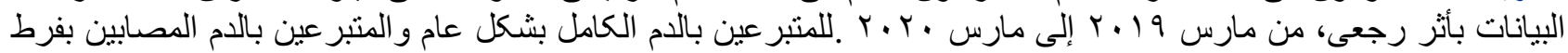

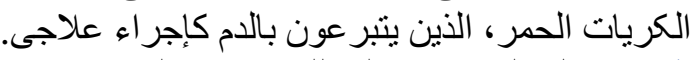

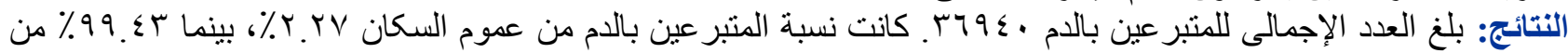

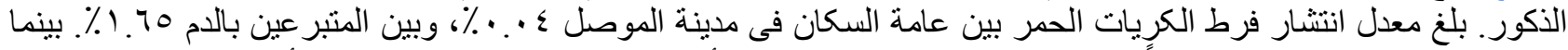

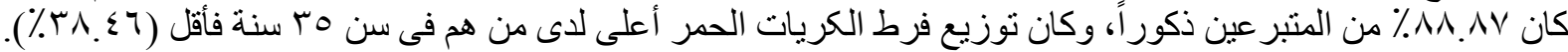

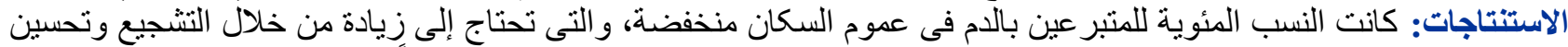

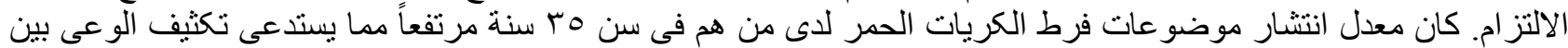
تلكى الفئات العمرية المنتجة.

الكلمات المفتاحية: التبرع ، الهيموكلوبين ، حجم الخلايا المكدسة ، فرط كريات الدم الحمر ، التدخين. 


\section{INTRODUCTION}

T he Mosul Central Blood Bank depends on voluntary and involuntary (replacement) blood donations. The bank is responsible for the recruitment of donors, testing donated blood for $\mathrm{ABO}$ and $\mathrm{Rh}$ blood groups, for viral and bacterial infective agents, and the preparation, storage and issue of blood and blood components; packed red blood cells (PRBCs), fresh frozen plasma, platelet concentrate, cryoprecipitate and filtered products.

Safe blood products, if correctly administered, with all standards are applied in, anyhow, it will carry many risks. If these standards are poorly conducted, then the transfusion is extremely hazardous. Therefore, any transfusion should not have carried out only after it is really indicated, after $\mathrm{ABO}$ and $\mathrm{Rh}$ grouping and after all donors screening for transfusion transmitted diseases as hepatitis B, C viral infections, human immune deficiency viral infection and syphilis. In addition to clinical examination of donors to ensure suitability for blood donation after exclusion of permanent and temporary deferral criteria ${ }^{1}$.

It is important to convert the replacement donor to voluntary one, to supply a safe and an adequate blood supply. It is essential to encourage the current donor to donate again and the eligible subject for donation to donate ${ }^{2}$.

The blood donations received at University of Maiduguri Teaching Hospital in north-eastern Nigeria, distributed into four categories; voluntary, family-replacement, commercial and pre-deposit autologous donations. Through the study's duration, the percentage of donations within the voluntary and family-replacement categories decreased by time. These falls were matched by increases in the percentages of commercial and autologous donations. At the end of the study period, the quantity of blood at the hospital was greatly insufficient and mostly derived from family and commercial donors, who were usually lower, in terms of blood safety. There is crucial requirement to fix this problem by introduction of a functional and national blood-transfusion service in Nigeria ${ }^{3}$.

Due to the aging of the US population and the fact that only $5 \%$ of population donate blood, these necessity to conserve safe, adequate and ready blood for the future ${ }^{4}$.

The causes of not returning to donate blood are different. In Shiraz, Iran, they figured out some of these causes and the main one was the absence of time due to working hours, they solved the problem by changing donation time and providing mobile teams at workplace which specified in advanced and limited the donation time. Second cause was the fear from needles, from acquiring a diseases or complications post donation, which were more frequent among females, they suggest the solution by reassurance and education of donors about blood donation. Altruism was the major inspiration for donation ${ }^{5}$.

Also the study which has been done in Saudi Arabia at 2011, revealed that $5 \%$ feel fear and $16 \%$ blame lack of time as the main causes of not to donate ${ }^{6}$.

The level of satisfaction with the current donation process was connected with the intention for future donation, which in turns had a positive link with male donors, locally living donors ${ }^{\text {}}$.

Polycythemia or erythrocytosis is an increase in RBCs, packed cell volume (PCV), hemoglobin ( $\mathrm{Hb})$ concentration. It could be primary erythropoietin (EPO) independent or secondary EPO dependent. Secondary polycythemia is the one which we can manipulate, it mostly caused by smoking.

As a normal physiology, oxygen transports, is the primary function of RBC. Primary erythrocytosis in dogs and cats is to a certain extent similar to that of humans. The EPO stimulates the erythroid precursors in the bone marrow to grow and mature toward maintaining an $\mathrm{RBC}$ mass to sustain enough oxygen delivery to the tissues ${ }^{8}$.

Elevated PCV could be due to primary proliferative polycythemia (primarily RBC mass is increased), or caused by secondary polycythemia, or by relative polycythemia (normal RBC mass with reduced plasma volume) ${ }^{9}$.

Primary erythrocytosis or called polycythemia vera (PV) is a common type of myeloproliferative diseases and considered as malignant one according to the International Classification of Diseases for Oncology, 3rd edition (ICD-O-3) published by the World Health Organization in $2000^{10}$. PV is EPO - independent hematopoietic neoplastic disease, the diagnosis is made after exclusion of other causes and finding of inappropriate low serum EPO levels ${ }^{8}$. While secondary polycythemia is an EPO-driven elevation in PCV which arises most frequently as a response to chronic hypoxemia ${ }^{11}$. The secondary is usually caused by smoking, renal neoplasia, hypoxic cardiomyopathy, being in high altitude and sever obesity ${ }^{10}$.

The differentiation of primary from secondary causes is important. From history, physical examination, laboratory tests and imaging tests may reveal the cause behind the erythrocytosis ${ }^{8}$.

Even though $\mathrm{PV}$ is linked with increased death rate, many patients have long survival rate. The understanding of Janus Kinase 2 (JAK2) mutations facilitates the understanding of the pathogenesis of $\mathrm{PV}^{12}$. The detection of JAK2V617F mutation was marked with the researcher Barbara and her colleagues in $96 \%$ of patients with PV, in addition to other earlier studies 13 . Proving mutation in 
patient with myeloproliferative neoplasm is not only necessary for diagnosis but also for future prognosis ${ }^{14}$.

Pruritis, erythromelalgia, splenomegaly, gastrointestinal disturbance, others as weakness, headaches, are often be present in PV, usually the coexistence of a high hematocrit with splenomegaly, leukocytosis, thrombocytosis is indicator for primary one ${ }^{15}$. Whereas other symptoms as dyspnea are more expected to be present in secondary polycythemia where smoking is the most frequent cause ${ }^{16}$.

Familial polycythemia is also common, although little researches have been done about. That is when one individual in the family has polycythemia, no further studies were made about his relatives, although they have splenomegaly or cyanosis ${ }^{17}$.

El Zayadi and Selim et al, gave a conclusion that heavy cigarette smoking in patients having chronic hepatitis $\mathrm{C}$ may lead to erythrocytosis. Phlebotomy with stop smoking ameliorates clinical condition ${ }^{9}$.

Claudia and Zilberberg et al studied the prevalence of polycythemia in patients with chronic obstructive pulmonary disease (COPD), and its effects on outcome of COPD. Polycythemia present in $5 \%$ of COPD patient and without greater hypoxemia or any other complains of polycythemia ${ }^{18}$.

Polycythemia also can be found in female with uterine fibroid. After hysterectomy, the $\mathrm{Hb}$ level and RBC count set up and were conserved in the next 22 months ${ }^{19}$.

The same for veterinary patients like dogs and cats, increased PCV leading to relative or absolute erythrocytosis, and both of which has different treatment strategies. Absolut erythrocytosis is consistent with high PCV and reticulocytosis. Relative erythrocytosis is seen in fluid loss, dehydration, vascular redistribution, all can be easily corrected with replacement fluid therapy, and treating the cause ${ }^{8}$.

\section{METHODS}

\section{1) Study Design}

Through an epidemiological study of a biometric data, it has been retrospectively collected over a period of one year (from March 2019 to March 2020) and descriptively analysed.

A total of 36940 blood units were collected from voluntary and replacement donors in Mosul Central Blood Bank at Nineveh governorate, Iraq.

On attendance, the medical records of this cohort of participants were reviewed by a medical doctor. Capillary blood was then collected from the participants who were attending to the consultant doctors in consolatory units at Mosul Central Blood Bank.
The donors were routinely checked for $\mathrm{ABO}$ and $\mathrm{Rh}$ blood groups, $\mathrm{Hb}$ concentration and PCV. The donated units were then serologically screened for hepatitis B, C viral infection, human immune deficiency viral infection and syphilis.

\section{2) Selection and Description of Participants}

\section{Inclusion and Exclusion Criteria:}

Selection of blood donors was based on regularly reviewed selection criteria according to the directions of Iraqi Ministry of Health (https://moh.gov.iq/) and WHO guidelines on assessing donor eligibility for blood donation ${ }^{20,21}$.

\section{Inclusion criteria:}

Participants were enrolled in this study and considered as healthy blood donors if they were:

1. Aged 18-65 years.

2. Weighing more than $55 \mathrm{Kg}$ for male and more than $50 \mathrm{Kg}$ for female donors.

3. Having $\mathrm{Hb}$ concentration of $13.5-16.0 \mathrm{~g} / \mathrm{dL}$ for male and $12.5-15.5 \mathrm{~g} / \mathrm{dL}$ for female. And PCV of $42-48 \%$ for male and $40-47 \%$ for female.

4. Having blood pressure of $180 / 100 \mathrm{mmHg}$ or less 22

5. Having pulse rate of $60-100$ beat per minute.

6. Having frequency of donation; for male being every 12 weeks or up to four times a year, for female being every 16 weeks or up to three times a year.

7. Having normal body temperature of not more than $37.6^{\circ} \mathrm{C}$.

Exclusion criteria:

Participants were not considered as healthy blood donors, and were never have allowed to donate blood to someone else, they were excluded from healthy donation and deferred permanently if they were having:

1.Any transfusion transmitted diseases like hepatitis B, C viral infections, human immune deficiency viral infection, syphilis.

2. Haematological disorders: as polycythemia i.e. male having $\mathrm{Hb}$ of $16.5 \mathrm{~g} / \mathrm{dL}$ or more, PCV of $49 \%$ or more, or female having $\mathrm{Hb}$ of $16.0 \mathrm{~g} / \mathrm{dL}$ or more, PCV of $48 \%$ or more, according to WHO criteria to diagnose polycythemia; (polycythemic male's $\mathrm{Hb}$ value is $\geq 16.5 \mathrm{~g} / \mathrm{dL}$ and $\mathrm{PCV}$ is $\geq 49 \%$, and polycythemic female's $\mathrm{Hb}$ value is $\geq 16.0 \mathrm{~g} / \mathrm{dL}$ and $\mathrm{PCV}$ is $\geq 48 \%$ ).

3. Also thalassemia, sickle cell anemia, glucose-6phosphate dehydrogenase deficiency, hereditary spherocytosis, thrombocytopenia, hemophilia $A$ and B.

4.Cardiovascular diseases: as ischemic heart diseases, venous thrombosis and thrombophlebitis. 
5. Gastrointestinal diseases as bleeding peptic or duodenal ulcers.

6. Metabolic and endocrine diseases as insulin dependent diabetes mellitus.

7.Immunological diseases: as vitiligo, rheumatoid arthritis, asthma, systemic lupus erythematosus.

8. Chronic renal diseases.

9.Central nervous system diseases: as cerebrovascular diseases, epilepsy, dementia, multiple sclerosis.

10. Malignant diseases.

11. On human growth hormone, addicts and homosexuals.

Participants were not considered as healthy blood donors, were excluded from healthy donation temporarily, then would be allowed to donate blood to someone else once improve, they have temporary deferral criteria. These participants can donate blood after:

1.Surgical intervention: after six months, or after one year if during surgery blood was transfused.

2.Blood thinners: three days after aspirin (acetyl salicylic acid) cutout and 14 days after plavix (clopidogrel) cutout (if to donate platelet).

3. Anti-malarial drugs: three years after stopping.

4. After transfusion of blood or blood products by one year.

5. Antibiotics: two weeks after cutout.

6. Minor tooth operation: 72 hours post tooth extraction.

7. After hijamat (wet cupping): six months.

8.For females: should not donate during menstruation, pregnancy, abortion or lactation.

9. Source ${ }^{20}$.

\section{3) Technical Information}

Enrolled participants were interviewed by medical doctors and examined thoroughly. Any chronic diseases like lung, renal, cardiac diseases were recorded. Past medical, surgical and family history also were disclosed. Any permanent or temporary deferral criteria were excluded. Habits like cigarette smoking and pipe smoking (narghile) were documented.

$\mathrm{ABO}$ and $\mathrm{Rh}$ blood grouping is done by standard tube method using commercial antisera. $\mathrm{Hb}$ level measurement is conducted using hemoglobinometer (hemoCue $\mathrm{Hb} 301$ analyser), and the PCV level measurement is performed using microhematocrit method after centrifugation in the microhaematocrit centrifuge (Hettich Zentrifugen- Haematokrit 210).

\section{4) Statistics}

Demographic (age, gender) and laboratory $(\mathrm{Hb}$, PCV) findings of participants were entered in the program; Statistical Package for Social Science
(SPSS) and analysed subsequently, through descriptive analysis.

\section{RESULTS}

During a period from March 2019, to March 2020, A total of 36940 blood donors attended the Mosul Central Blood Bank in Mosul city at Nineveh Governorate, Iraq.

Among those total donors, 36730 (99.43\%) were male and $210(0.57 \%)$ were females.

The population in Mosul city during 2019 were 1630000 (https://populationstat.com/iraq/mosul). The percentage of people who donates blood as a whole among general population is $2.27 \%$. While the percentage of healthy blood donors among general population is $2.23 \%$.

Among those 36940 blood donors, there are 611 subjects were excluded, since they have high $\mathrm{Hb}$ level (of $16.5 \mathrm{~g} / \mathrm{dL}$ or more for male, or of $16.0 \mathrm{~g} / \mathrm{dL}$ or more for female), or high PCV concentration (of $49 \%$ or more for male, or of $48 \%$ or more for female), according to the WHO criteria to diagnose polycythemia; (male with $\mathrm{Hb}$ value of $\geq 16.5 \mathrm{~g} / \mathrm{dL}$ and PCV of $\geq 49 \%$, and female with $\mathrm{Hb}$ value of $\geq$ $16.0 \mathrm{~g} / \mathrm{dL}$ and PCV of $\geq 48 \%$, are considered as having a case of polycythemia).Their donation was therapeutic.

The prevalence of polycythemic subjects among total blood donors in Mosul city is $1.65 \%$, while among general population of Mosul city is $0.04 \%$.

Polycythemic subjects' characteristics of age and genders are as follow; among those 611 polycythemic subjects, there were $543(88.87 \%)$ males, and $68(11.13 \%)$ females.

And $235(38.46 \%)$ aged 35 years and less, 190 $(31.10 \%)$ aged $36-50$ years and $186(30.44 \%)$ aged 51 years and more, as shown in figure 1.

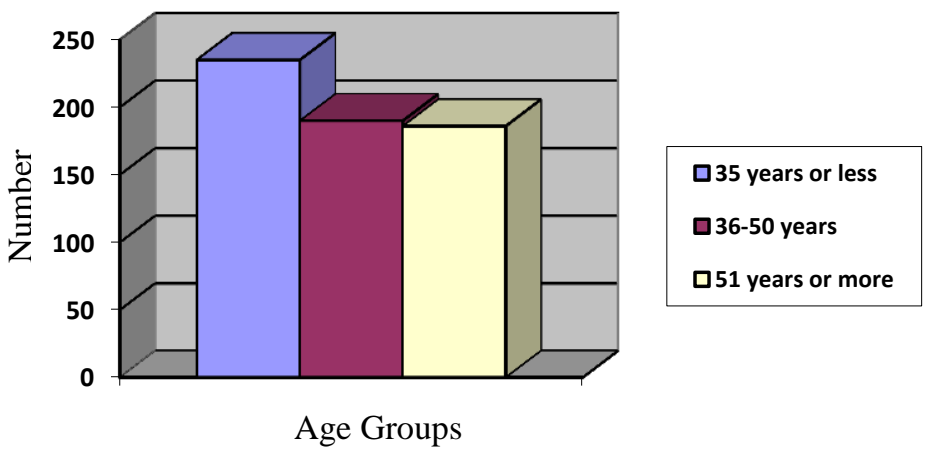

Figure 1 The distribution of polycythemic subjects among different age groups.

Their mean $\mathrm{Hb}$ is $18.23 \mathrm{~g} / \mathrm{dL}$, median is 18.00 $\mathrm{g} / \mathrm{dL}$, with range of (16.00-23.40) as shown in table 1,2 , while their mean PCV is $52.86 \%$, median is $52.20 \%$, with range of (46.40-67.86) as shown in table 3, 4 . 
Table 1 The characteristics of polycythemic subjects' $\mathrm{Hb}$ in relation to genders are as follows:

\begin{tabular}{|l|l|l|l|l|l|l|}
\hline Gender & Mean $^{\star}$ & $\mathrm{N}$ & SD & Median $^{\star}$ & Minimum $^{\star}$ & Maximum $^{\star}$ \\
\hline Male & 18.29 & $543(88.87 \%)$ & 1.18 & 18.00 & 16.50 & 23.40 \\
\hline Female & 17.76 & $68(11.13 \%)$ & 1.14 & 18.00 & 16.00 & 20.90 \\
\hline Total & 18.23 & $611(100.00 \%)$ & 1.19 & 18.00 & 16.00 & 23.40 \\
\hline
\end{tabular}

${ }^{*} \mathrm{~g} / \mathrm{dL}$

Table 2 The characteristics of polycythemic subjects' $\mathrm{Hb}$ in relation to age groups are as follows:

\begin{tabular}{|l|l|l|l|l|l|l|}
\hline Age group & Mean $^{*}$ & $\mathrm{~N}$ & SD & Median $^{*}$ & Minimum $^{*}$ & Maximum $^{*}$ \\
\hline 35 and below & 18.32 & $235(38.46 \%)$ & 1.21 & 18.00 & 16.00 & 23.00 \\
\hline $36-50$ & 18.34 & $190(31.10 \%)$ & 1.30 & 18.00 & 16.00 & 23.40 \\
\hline 51 and above & 18.00 & $186(30.44 \%)$ & 0.99 & 18.00 & 16.00 & 21.00 \\
\hline Total & 18.23 & $611(100.00 \%)$ & 1.19 & 18.00 & 16.00 & 23.40 \\
\hline
\end{tabular}

${ }^{*} \mathrm{~g} / \mathrm{dL}$

Table 3 The characteristics of polycythemic subjects' PCV in relation to genders are as follows:

\begin{tabular}{|l|l|l|l|l|l|l|}
\hline Gender & Mean $^{\dagger}$ & $\mathrm{N}$ & $\mathrm{SD}$ & Median $^{\dagger}$ & Minimum $^{\dagger}$ & Maximum $^{\dagger}$ \\
\hline Male & 53.03 & $543(88.87 \%)$ & 3.42 & 52.20 & 47.85 & 67.86 \\
\hline Female & 51.50 & $68(11.13 \%)$ & 3.30 & 52.20 & 46.40 & 60.61 \\
\hline Total & 52.86 & $\begin{array}{l}611 \\
(100.00 \%)\end{array}$ & 3.44 & 52.20 & 46.40 & 67.86 \\
\hline
\end{tabular}

† percent

Table 4 The characteristics of polycythemic subjects' PCV in relation to age groups are as follows:

\begin{tabular}{|l|l|l|l|l|l|l|}
\hline Age group & Mean $^{\dagger}$ & $\mathrm{N}$ & $\mathrm{SD}$ & Median $^{\dagger}$ & Minimum $^{\dagger}$ & Maximum $^{\dagger}$ \\
\hline 35 and below & 53.13 & $235(38.46 \%)$ & 3.50 & 52.20 & 46.40 & 66.70 \\
\hline $36-50$ & 53.19 & $190(31.10 \%)$ & 3.77 & 52.20 & 46.40 & 67.86 \\
\hline 51 and above & 52.19 & $186(30.44 \%)$ & 2.87 & 52.20 & 46.40 & 60.90 \\
\hline Total & 52.86 & $611(100.00 \%)$ & 3.44 & 52.20 & 46.40 & 67.86 \\
\hline
\end{tabular}

† percent

\section{DISCUSSION}

The current study studied the percentage of blood donors and the prevalence of polycythemia in Mosul city, Nineveh governorate, Iraq.

The total number of blood donors in Mosul Central Blood Bank was 36940. Among those 36940 donors, 36730 (99.43\%) were male and 210 $(0.57 \%)$ were females, which is comparable, although higher than the study done in Chennai, India, which found that 436 (93\%) of donors were males and $36(7 \%)$ were female donors ${ }^{20}$.

It also compatible, but higher than Oswalt's finding, who said that 66 to $91 \%$ of blood donors were male ${ }^{23}$.

With regard to Vanita Ahuja work, 2016, the proportion of men was $96.60 \%$ in their study, which is comparable with the current study $(99.43 \%)$, although slightly higher ${ }^{7}$.

It also in accordance, although higher than the finding of Bhalodia $\mathrm{N}$ and Patel $\mathrm{A}$ et al, who found $94 \%$ of his college student sample were male ${ }^{2}$.
Although Babita and coworkers also found that the male donors are higher than the female ones, but the knowledge and awareness regarding blood donation is higher among females. They do not donate because of fear from the process. Small incentives like certificates, providing transport of blood donors may make a difference.

The percent of blood donors among general population is small $2.27 \%$, especially when we know that only $(2.23 \%)$ of general population are healthy blood donor, while others might not, which necessity more researches to learn what "captures" donors and how to improve the psychological commitment to continue to donate blood $^{24}$. May be one of the causes of little blood donors are the lack of time. Providing mobile teams may resolve the issue ${ }^{5}$.

In study done in Chennai, india, at 2013, they found that this small number of blood donor could be due to, the donor does not have a time to donate and $57 \%$ wish to have opportunity. While 
$55 \%$ of donors felt that the fear of pain is the main cause of reluctance from blood donation ${ }^{25}$.

The small number of donors are lower than the researcher' Babita cross sectional study among students. He found that $55.40 \%$ of his sample donate blood, and that $57.10 \%$ have adequate knowledge regarding blood donation, but not all of them will proceed to donate ${ }^{26}$. And $99 \%$ showed positive attitude toward blood donation and its significance for patients, $91 \%$ agreed that blood donation is a religious process ${ }^{6}$.

Only $5 \%$ of people in US donate blood each year, which is higher than the current study's finding $(2.27 \%)$. This $5 \%$ is hard to meet the need in US, this will need to raise the consciousness about ensuring safe, adequate blood supply for the future 4

Whether those 36940 were first time blood donors or regular donors was unclear, but blood banks need all the first time blood donors to come back to donate another time, as Ahuja and Saluja said, this depend on the satisfaction of the donors with the existing donation, which impact their intent to donate next times. If the quality of blood bank services were improved, the intention to come back in the upcoming months will be improved too 7.

Bhalodia and his coworkers, observed that most of voluntary donors were belonged to age group 4150 years (2), while they belong to those aged 35 years or less in the current study. In the present study, the number of female donors is small, 210 $(0.57 \%)$, this is in accordance with D. Royse and Doochin, 1995 who said that women are underrepresented among blood donors ${ }^{24}$.

In the current study, the subjects were considered as polycythemic if they have $\mathrm{Hb}$ level $\geq 16.5 \mathrm{~g} / \mathrm{dL}$, $\mathrm{PCV}$ of $\geq 49 \%$ in male and $\mathrm{Hb}$ of $\geq 16.0 \mathrm{~g} / \mathrm{dL}$, PCV of $\geq 48 \%$ in female, according to the WHO criteria to diagnose polycythemia.

The current study's sample size of polycythemic subjects was 611 , while that of Ma and Vanasse et al was very large US population. They performed the first study in 2008 to assess the prevalence of PV and essential thrombocythemia in US. For example, at 2003 , more than 136,00 patients suffered from these two malignancies in the US, in addition to the demographic changes, which alone will further increase the burden of these diseases in the foreseeable future 27 .

The current study assesses the prevalence of polycythemia in different age groups, and found that the prevalence differs with age, which is in concordance with $\mathrm{Ma}$ and his colleagues, who offered age specific prevalence and found that the prevalence differs in different age groups. But they said that the prevalence increases by age ${ }^{27}$, while the current study found that it is most prominent in those aged 35 and less (38.46\%).

In the current study, the average (mean) hematocrit was $52.86 \%$, with (46.40 - 67.86) as a range, while Nadeem $O$ and Gui et al, 2013, found out that the average hematocrit was $53.50 \%$ which approximate to the current study, with (50.1063.40) as a range ${ }^{11}$.

Nathany et al, 2019 achieved a retrospective study during 2013 to 2015, and discovered that out of 26 patients previously diagnosed with PV, 21 were found to comply with the new 2016 revision of the WHO Criteria, with male predominates, which is compatible with this study, although the small sample size of female subjects may affect this predominance. The Nathany study's median values of $\mathrm{Hb}, \mathrm{PCV}$ were $17.50 \mathrm{gm} / \mathrm{dL}, 56.70 \%$ respectively, which is lower in regard to $\mathrm{Hb}$ and higher in regard to PCV, than the present study's median values of $\mathrm{Hb}$ and PCV $(18.00 \mathrm{~g} / \mathrm{dL}$, $52.20 \%$ ) respectively ${ }^{28}$.

\section{CONCLUSION}

The blood banks need to ensure safe and sufficient blood supply; this is the challenge.

the percentages of blood donors in general population was low, which need to increase through encouragement and improving of commitment, educational programs to avoid negative motivation, like fear of needle or sight of blood or pin prick, medical excuse etc. Preservation of the prior donors may be of more importance than motivation of new one.

The prevalence of polycythemic subjects in those aged $\leq 35$ years was high which necessity intensification of the awareness among those productive age groups. Awareness to understand the arterial and venous thromboembolism complications associated with polycythemia, especially the one which we can control; secondary polycythemia due to smoking.

Funding Information: None.

Conflict of Interest Declaration: There are no conflicts of interest to declare.

\section{REFERENCES}

1.WHO. The Clinical Use of Blood in Medicine, Obstetrics, Paediatrics, Surgery and Anaesthesia, Trauma and Burns: Geneva; 2001.

2. Jignasa NB, Kinara AP, Hiren VO. Psychosocial variables of highly motivated voluntary blood donors at blood bank of a medical college. National Journal of Medical Research. 2012; 2(1):39-41. 
3. Ahmed SG, Ibrahim UA, Hassan AW. Adequacy and pattern of blood donations in north-eastern Nigeria: the implications for blood safety. Journal of Annals of Tropical Medicine and Parasitology. 2007;101 (8):725-31.

4.Gillespie TW, Hillyer CD. Blood donors and factors impacting the blood donation decision. Transfusion medicine Reviews.2002;16(2):11530.

5.Kasraian L. Causes of discontinuity of blood donation among donors in Shiraz, Iran: crosssectional study. Sao Paulo Medical Journal. 2010;128(5).

6. Gader AGMA, Osman AMA, Gahtani FHA, Farghali MN, Ramadan AH, Al-Momen AKM. Attitude to blood donation in Saudi Arabia. Asian Journal of Transfusion Science.2011; 5(2):121-6.

7.Ahuja V, Saluja GP. Assessment of blood donors' perception in a hospitalized blood bank and their intention for future donation. Health and Population: Perspectives and Issues. 2009; 32(2):78-85.

8. Nitsche EK. Erythrocytosis in dogs and cats: diagnosis and management. Compendium on Continuing Education for the Practising Veterinarian-North American Edition. 2004; 26(2):104-21.

9.El-Zayadi A-R, Selim O, Hamdy H, El-Tawil A, Moustafa $\mathrm{H}$. Heavy cigarette smoking induces hypoxic polycythemia (erythrocytosis) and hyperuricemia in chronic hepatitis $\mathrm{C}$ patients with reversal of clinical symptoms and laboratory parameters with therapeutic phlebotomy. The American Journal of Gastroenterology. 2002; 97(5):1264.

10. Jack A, Percy C, Sobin L, Shanmugarathan S, Whelan S. International Classification of Diseases for Oncology: ICD-O: World Health Organization. 2000.

11. Nadeem O, Gui J, Ornstein DL. Prevalence of venous thromboembolism in patients with secondary polycythemia. Clinical and Applied Thrombosis/ Hemostasis. 2013; 19(4):363-6.

12. Griesshammer M, Gisslinger H, Mesa R. Current and future treatment options for polycythemia vera. Annals of Hematology. 2015;94(6):901-10.

13. Monte-Mór BdCR, Cunha AFd, Pagnano KBB, Saad ST, Lorand-Metze I, Costa FF. JAK2 V617F prevalence in Brazilian patients with polycythemia vera, idiopathic myelofibrosis and essential thrombocythemia. Genetics and Molecular Biology. 2007;30(2):336-8.

14. Barbui $T$, Thiele J, Gisslinger $H$, Kvasnicka HM, Vannucchi AM, Guglielmelli P, et al. 2018. The WHO classification and diagnostic criteria for myeloproliferative neoplasms: document summary and in-depth discussion. Blood Cancer Journal. 2016; 8(2):1-11.

15. Stuart BJ, Viera AJ. Polycythemia vera. American Family Physician.2004; 69(9):2139-44.

16. Ferrant $A$. What clinical and laboratory data are indicative of polycythemia and when are blood volume studies needed? Nouvelle Revue Francaise d'Hematologie. 1994. 36(2):151-4.

17. Anthony Spodaro MD, Claude E. Forkner MD. Benign familial polycythemia. Arch Intern Med. 1933; 52(4):593-602.

18. Cote C, Zilberberg M, Mody SH, Celli B. The prevalence of polycythemia in a chronic obstructive pulmonary disease (COPD) cohort. Chest. 2005; 128(4):264S.

19. Engel HW, Singer K. Polycythemia with fibroids. Journal of the American Medical Association. 1955; 159(3):190-1.

20. Ja'far I, Alwahed Y. Guidelines for standard operating procedures in blood transfusion centers 2013.

21. WHO. Blood donor selection: guidelines on assessing donor suitability for blood donation 2012. $238 \mathrm{p}$.

22. Blaney KD, Howard PR. Blood Banking and Transfusion Practices: Elsevier; 2013. 409 p.

23. Oswalt R. A review of blood donor motivation and recruitment. the Journal of AABB.1977;17(2):123-35.

24. Royse D, Doochin KE. Multi-gallon blood donors: who are they? The Journal of AABBTransfusion 1995 Oct;35(10):826-31.

25. Uma S, Arun R, Arumugam P. The knowledge, attitude and practice towardsblood donation among voluntary blood donation, Chennai, India. Journal of Clinical Diagnostic Research. 2013; 7(6):1043-6.

26. Raghuwanshi B, Pehlajani NK, Sinha MK. Voluntary blood donation among studentsacross- sectional study on knowledge and practice vs. attitude. Journal of Clinical and Diagnostic Research. 2016; 10(10).

27. Ma X, Vanasse G, Cartmel B, Wang $Y$, Selinger HA. Prevalence of polycythemia vera and essential thrombocythemia. American Journal of Hematology. 2008; 83(5):359-62.

28. Nathany S, Laxminarayana SLK, Tewari S, Belurkar S, Khanna R, Manohar C. Impact of World Health Organization (WHO) Revised Criteria-2016 on the Diagnosis of Polycythemia Vera. Indian Journal of Hematology and Blood Transfusion. 2019 Oct;36(3):477-483. 